\title{
MICROBIOLOGICAL STUDIES OF MACARONI AND VEGETABLE SALADS IN WAAKYE, A LOCAL STREET FOOD
}

\author{
A. Adu-GYAmFi AND J. NKETSIA-TABIRI \\ Department of Food Science \& Radiation Processing, Biotechnology \& Nuclear Agriculture \\ Research Institute, P. O. Box LG80, Legon, Ghana
}

\begin{abstract}
The microbiological quality of macaroni and vegetable salads served with waakye, was investigated. Aerobic mesophiles counts (AMC), coliforms counts (CC) and moulds and yeasts counts (MYC) were estimated, and the coliform profiles for different samples of macaroni (raw, local/ imported, laboratory-cooked) served with waakye, and vegetable salads served with waakye were determined. Raw macaroni (local and imported) had AMC of 3.6 and $3.0 \log _{10} \mathrm{CFU} / \mathrm{g}, \mathrm{MYC}$ of 1.9 and $1.0 \log _{10} \mathrm{CFU} / \mathrm{g}$ and no CC, respectively. Laboratorycooked local samples had AMC of $2.4 \log _{10} \mathrm{CFU} / \mathrm{g}$ and $3.3 \log _{10} \mathrm{CFU} / \mathrm{g}$ (after $4 \mathrm{~h}$ storage) and no MYC. Macaroni obtained from vendors had AMC mean of 3.1-8.4, CC mean of 2.5-7.3 and MYC mean of 0$4.1 \log _{10} \mathrm{CFU} / \mathrm{g}$ depending on time of sampling. Vegetable salads sampled at early and late morning had AMC of 6.9 and 7.6, CC of 5.7 and 6.4, MYC of 4.9 and $5.4 \log _{10} \mathrm{CFU} / \mathrm{g}$, respectively. Six coliforms were detected on macaroni and three were detected in addition to Salmonella spp. on vegetable salads. No significant difference was recorded in the microbial load of raw local and imported macaroni. Cooking improved the microbial quality of raw macaroni (AMC of $2.4 \log _{10} \mathrm{CFU} / \mathrm{g}$ ). Generally, there were increases of 3-5 log cycles in the AMC, CC and MYC in macaroni sampled from waakye vendors in the morning (early and late) compared to those at dawn. Although the nature of raw macaroni and its cooking are adequate, cross-contamination from vegetable salads during the holding and bulk display periods cause deterioration in microbial quality of macaroni in waakye. There is the need to educate vendors on simple preventive steps of keeping food hygienically safe.
\end{abstract}

\section{Résumé}

Adu-gyamfi, A. \& Nketsia-Tabiri, J.: Etudes microbiologiques de macaroni et de macédoine de légumes en wakye une nourriture locale en plein air. La qualité microbiologique de macaroni et de macédoine de légumes servis avec waakye était étudiée. Les comptes mésophiles aerobie (CMA), les comptes de coliformes (CC) et les comptes de moisissures et de levures (CML) étaient estimés et les profils de coliforme de différents échantillons de macaroni (cru, local/importé, cuit au laboratoire et waakye) et les macédoines de légumes servis avec waakye étaient déterminés. Le macaroni cru (local et importé) avait les CMA de 3.6 et $3.0 \log _{10}$ CFU/g CML de 1.9 et 1.0 $\log _{10} \mathrm{CFU} / \mathrm{g}$, et aucun CC respectivement. Les échantillons locaux cuits au laboratoire avaient CMA de $2.4 \log _{10} \mathrm{CFU} / \mathrm{g}$ et $3.3 \log _{10} \mathrm{CFU} / \mathrm{g}$ (après 4-heure de stockage) et nulle CML. Le macaroni obtenu de marchandes avait CMA moyen de 3.1 à 8.4, CC moyen de 2.5 à 7.3 et CML moyen de 0 à $4.1 \log _{10} \mathrm{CFU} / \mathrm{g}$ selon le temps d'échantillonage. La macédoine de légumes échantillonée au début et à la fin de la matinée avait respectivement CMA de 6.9 et 7.6, CC moyen de 5.7 et 6.4 , CML de 4.9 et $5.4 \log _{10} \mathrm{CFU} / \mathrm{g}$. Six coliformes étaient dépistés sur le macaroni et 3 étaient dépistés en plus de Salmonella spp. sur la macédoine de légumes. Aucune différence considérable n'était enregistrée de la quantité microbienne de macaroni cru, local et importé. La cuisson améliorait la qualité microbienne de macaroni cru (CMA de $2.4 \log _{10} \mathrm{CFU} /$ g). En général il y avait des augmentations de 3 à 5 cycles log dans le CMA, CC et CML de macaroni échantillonné de marchandes de waakye dans la matinée (au début et à la fin) comparé à ceux de l'aube. Bien que la nature de macaroni cru et ses cuissons soit adéquate, la contamination croisés de macédoine de légumes pendant le stockage et les périodes de l'étalage en gros provoque la détérioration dans la qualité microbienne de macaroni en waakye. Il est nécessaire d'éduquer les marchandes sur les mesures préventives simples de garder la nourriture hygiéniquement favorable à la santé. 


\section{Introduction}

Street foods (ready-to-eat foods sold in the informal sector) form an important and wellestablished sector of the food industry in Ghana. They are readily available, inexpensive, nutritionally-balanced and also provide a source of income for the vendors (Ekanem, 1998; Swanepoel et al., 1995 Dawson \& Canet, 1991). Despite these benefits, concerns have been raised about their safety and quality because most of the vendors lack training in basic food safety practices concerning raw material acquisition, food preparation, storage, handling, and final delivery to the consumer (Moy, Hazzard \& Kaferstein, 1997; Bryan et al., 1988).

Information on street foods in developing countries is not readily available. However, studies on street-vended foods in USA, Asia, and a few African countries have revealed high bacterial counts and presence of foodborne bacterial pathogens (Mosupuye \& von Holy, 1999; Bryan et al., 1997; FAO/Ghana, 1997). Aerobic mesophilic count (AMC) exceeding $4 \times 10^{5} \mathrm{CFU} / \mathrm{g}$, Staphylococcus aureus count exceeding $3 \times 10^{4}$ CFU/g and Bacillus cereus count exceeding $2 \times 10^{5}$ $\mathrm{CFU} / \mathrm{g}$ have been reported for vegetable salads and pepper sauce served with street foods in Ghana (FAO/GHANA, 1997). According to the World Health Organisation, effects of microbiological hazards such as Salmonella, Campylobacter jejuni and enterohaemorrhagic Escherichia coli on food safety is now a major public health concern worldwide (WHO, 2002).

Despite the poor hygienic quality and potential food safety problems, street foods such as waakye (co-boiled rice and beans), jollof and fried rice containing macaroni continue to enjoy tremendous patronage owing to their availability and affordability. Reports indicate that there is persistent contamination of macaroni and other pasta products with Staphylococcus spp., Escherichia coli, and Bacillus spp. during manufacture (Lopez et al., 1998; Castelvetri, Abroggi \& Gola, 1986; Pasolini, Aloi \& Ceralli,
1981; Lee, Staples \& Olson., 1975). However, few studies have been conducted on the impact of macaroni and other minimally-processed accompaniments such as vegetable salads on the overall hygienic quality of street foods in the country. A public health risk may be associated with the consumption of such foods. There is, therefore, the need to investigate the potential sources of microbiological contamination of such accompaniments that are served with street foods. This could provide baseline information for effective microbiological risk assessment of street foods. Development of a national strategy to reduce food-related risks requires knowledge about levels of potential pathogens and factors influencing them. The aim of this study is to investigate the factors influencing microbiological quality of macaroni and vegetable salads served with waakye, a local street food.

\section{Materials and methods \\ Experimental design}

Samples of cooked macaroni (locally produced) and corresponding vegetable salads (lettuce, tomato, onion, cabbage) used for the study were bought at different times in the morning from waakye vendors in three suburbs of Accra (Dome, Haatso and Madina). Samples of raw local and imported macaroni were also obtained from the markets (Madina and Dome). A portion of the raw local sample was cooked in the laboratory by boiling $150 \mathrm{~g}$ in $500 \mathrm{ml}$ of distilled water for $5 \mathrm{~min}$. The cooked macaroni was held under ambient laboratory conditions $\left(26-28{ }^{\circ} \mathrm{C}\right)$ up to $4 \mathrm{~h}$. In all instances, samples were procured in sterile polyethylene sachets, kept at $3-5{ }^{\circ} \mathrm{C}$ before analysis within $2 \mathrm{~h}$. Dawn samples were obtained just after cooking without bulk display. Samples procured from vendors at dawn, early morning and late morning had average holding periods of $1 / 2,21 / 2$ and $41 / 2 \mathrm{~h}$, respectively.

The seven samples of macaroni and two samples of vegetable salads used were: 


\section{Macaroni}

i. raw (local) market sample,

ii. raw (imported) market sample,

iii. laboratory-cooked sample (no holding),

iv. laboratory-cooked sample (held under ambient conditions for $4 \mathrm{~h}$ ),

v. sample from waakye vendors obtained at dawn (5.30 - 6.00 a.m.)

vi. sample from same waakye vendors obtained early morning (7.30 - 8.00 a.m.)

vii. sample from same waakye vendors obtained late morning (11.00 a.m. 12.00 p.m.).

Vegetable salads

i. sample of vegetable salads from same waakye vendors obtained early morning (7.30-8.00 a.m.)

ii. sample of vegetable salads from same waakye vendors obtained late morning (11.00 a.m. - 12.00 p.m.)

Three replicate samples of macaroni and four replicate samples of vegetable salads were obtained independently on different days.

\section{Microbiological analysis}

Five grammes of each sample were added to 45 $\mathrm{ml}$ peptone water $(1 \%$ peptone water $+0.5 \% \mathrm{NaCl})$ and homogenised with a blender (Waring Laboratory Blender, Christison, Germany) for 5 min. Microbial load determination was carried out using standard decimal dilution and plate count methods (APHA, 1976). Aerobic mesophilic counts were estimated on Plate Count Agar (Oxoid, UK) at $36{ }^{\circ} \mathrm{C} / 48 \mathrm{~h}$. Coliforms were estimated on Violet red bile agar (Merck, Germany) at $36{ }^{\circ} \mathrm{C} / 48$ h. Moulds and yeasts were estimated on Oxytetracycline $(0.01 \%)$ Glucose Yeast Extract Agar (Merck, Germany) at $28{ }^{\circ} \mathrm{C} / 4$ days.

For the detection of Salmonella and Shigella, $25 \mathrm{~g}$ of the sample were pre-enriched in $225 \mathrm{ml}$ of buffered peptone water for $24 \mathrm{~h}$ at $37^{\circ} \mathrm{C}$, followed by selective enrichment in Rappaport Vassiliadis Soy broth for $24 \mathrm{~h}$ at $41{ }^{\circ} \mathrm{C}$. Isolation was done on Xylose Lysine Deoxycholate agar for $24 \mathrm{~h}$ at $37^{\circ} \mathrm{C}$ followed by biochemical confirmation. For the detection of other coliforms, representative colonies from the coliform plates were purified by sub-culturing, and identified using morphological characteristics and standard biochemical tests. The tests used were Gram stain, citrate, catalase, oxidase, motility, nitrate, carborhydrate fermentations, Triple sugar iron and the IMViC tests with reference to Biochemical Tests for Identification of Medical Bacteria. (MacFaddin, 1980).

\section{Results}

Microbial load

The results for the microbial count and coliform isolates of macaroni and vegetable salads are shown in Tables 1 and 2. Raw local and imported samples of macaroni had aerobic mesophilic count (AMC) of 3.6 and $3.0 \log _{10} \mathrm{CFU} / \mathrm{g}$, moulds and yeasts count (MYC) of 1.9 and $1.0 \log _{10} \mathrm{CFU} / \mathrm{g}$ and no coliform count (CC), respectively (Table 1). Laboratory-cooked samples had AMC of 2.4 $\log _{10} \mathrm{CFU} / \mathrm{g}$ and $3.3 \log _{10} \mathrm{CFU} / \mathrm{g}$ (after $4 \mathrm{~h}$ storage). No MYC and CC were recorded for laboratory samples.

Macaroni obtained from waakye vendors had varying counts depending on the time samples were obtained. Samples of freshly cooked macaroni obtained at dawn had a fairly low AMC of $3.1 \log _{10} \mathrm{CFU} / \mathrm{g}, \mathrm{CC}$ of $2.5 \log _{10} \mathrm{CFU} / \mathrm{g}$ and no MYC. Macaroni obtained early or late morning had high AMC mean of 7.3-8.4 $\log _{10} \mathrm{CFU} / \mathrm{g}, \mathrm{CC}$ mean of 5.6-7.3 $\log _{10} \mathrm{CFU} / \mathrm{g}$ and MYC of 2.9-4.1 $\log _{10} \mathrm{CFU} / \mathrm{g}$. Early and late morning samples of vegetable salads also had AMC mean of 6.9-7.6 $\log _{10} \mathrm{CFU} / \mathrm{g}$, CC mean of 5.7-6.4 $\log _{10} \mathrm{CFU} / \mathrm{g}$ and MYC mean of 4.9-5.4 $\log _{10} \mathrm{CFU} / \mathrm{g}$.

\section{Coliform isolates}

No coliforms were isolated from raw macaroni and laboratory-cooked macaroni (Table 1). A variety of coliforms were, however, isolated from the macaroni obtained from waakye vendors. Two, four and six isolates were, respectively, detected 
TABLE 1

Microbial counts and coliform isolates of different samples of macaroni

\begin{tabular}{|c|c|c|c|c|}
\hline \multirow[t]{2}{*}{ Sample } & \multicolumn{3}{|c|}{${ }^{A}$ Microbial counts [log cfu/g] } & \multirow[b]{2}{*}{ Coliform isolates } \\
\hline & ${ }^{B} A M C$ & $C C$ & $M Y C$ & \\
\hline Raw(Local) & $3.6 \pm 0.3$ & ND & $1.9 \pm 0.2$ & None \\
\hline Raw(Imported) & $3.0 \pm 0.4$ & ND & $1.0 \pm 0.6$ & None \\
\hline Laboratory-cooked & $2.4 \pm 0.2$ & ND & ND & None \\
\hline Lab-cooked ${ }^{\mathrm{C}}(+4 \mathrm{~h}$ storage $)$ & $3.3 \pm 0.7$ & ND & ND & None \\
\hline Dawn sample $(+1 / 2 h$ storage) & $3.1 \pm 0.1$ & $2.5 \pm 0.4$ & ND & $\begin{array}{l}\text { Enterobacter spp., Serratia } \\
\text { spp. }\end{array}$ \\
\hline $\begin{array}{l}\text { Early morning sample } \\
(+21 / 2 \mathrm{~h} \text { storage })\end{array}$ & $8.4 \pm 0.5$ & $7.3 \pm 0.3$ & $2.9 \pm 0.7$ & $\begin{array}{l}\text { Escherichia coli, Klebsiella } \\
\text { spp., Enterobacter spp., } \\
\text { Citrobacter spp. }\end{array}$ \\
\hline $\begin{array}{l}\text { Late morning sample } \\
\left(+4 \frac{1}{2} \mathrm{~h} \text { storage }\right)\end{array}$ & $7.1 \pm 1.0$ & $5.6 \pm 0.6$ & $4.1 \pm 1.6$ & $\begin{array}{l}\text { Escherichia coli Serratia } \\
\text { marcescans, Klebsiella spp., } \\
\text { Enterobacter spp., Citrobacter } \\
\text { spp., Proteus spp. }\end{array}$ \\
\hline
\end{tabular}

${ }^{A}$ Mean of three independent experiments, mean \pm s.d. $(n=3)$; N.D: Not detected;

${ }^{B}$ AMC: Aerobic mesophilic count; CC: Coliform count; MYC: moulds and yeasts count;

${ }^{\mathrm{C}}$ Average storage/holding period.

TABLE 2

Microbial counts and coliform isolates of vegetable salads

\begin{tabular}{lcccl}
\hline Sample & \multicolumn{2}{c}{${ }^{A}$ Microbial Counts [log cfu/g] } & \\
\cline { 2 - 3 } & ${ }^{B} A M C$ & $C C$ & MYC & Coliform isolates \\
\hline $\begin{array}{l}\text { Early morning sample } \\
{ }^{C}(+21 / 2 \text { h storage })\end{array}$ & $6.9 \pm 0.2$ & $6.4 \pm 0.9$ & $4.9 \pm 0.1$ & $\begin{array}{l}\text { Enterobacter spp. } \\
\text { Klebsiella spp. }\end{array}$ \\
$\begin{array}{l}\text { Late morning sample(+41/2 h } \\
\text { storage })\end{array}$ & $7.6 \pm 0.3$ & $5.7 \pm 0.2$ & $5.4 \pm 0.5$ & $\begin{array}{l}\text { Citrobacter spp., Enterobacter } \\
\text { spp., Klebsiella spp., } \\
\text { Salmonella spp. }\end{array}$ \\
\hline
\end{tabular}

AMean of four independent experiments, mean \pm s.d. $(n=4)$; N.D: Not detected.

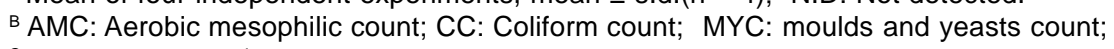

${ }^{\mathrm{C}}$ Average storage/holding period. 
on the dawn, early morning and late morning samples of macaroni. Enterobacter spp. were isolated from both dawn and morning samples (early and late) of macaroni. Escherichia coli and Klebsiella spp. were isolated from both morning samples of macaroni. In the case of the vegetable salads, three coliform isolates and Salmonella spp. were detected. Enterobacter spp. and Klebsiella spp. were isolated from both morning samples of the vegetable salads.

\section{Discussion}

Microbial analysis of a complete meal of waakye as well as macaroni, vegetable salads, stew, gari and fried fish revealed high total viable counts of $8.00 \log _{10}$ CFU/g. (Nketsia-Tabiri, Adu-Gyamfi \& Owusu-Biney, 2004). In that study, vegetable salads and macaroni were identified as the main accompaniments responsible for the high count in view of their equally high total viable count of 8.18-8.37 $\log _{10}$ CFU/g. With the exception of macaroni sold at dawn, this study has also revealed a high mean AMC of 6.9-8.4 $\log _{10} \mathrm{CFU} / \mathrm{g}$ for macaroni and vegetable salads obtained from vendors. However, a similar study on waakye without vegetable salads and macaroni reported a maximum AMC of $3.00 \log _{10} \mathrm{CFU} / \mathrm{g}$ (FAO/Ghana, 1997).

Microbial load of raw macaroni and effect of cooking

The processes of preparation, display and sale of macaroni sold with waakye involve microbial hazards at various critical points according to the Hazard Analysis and Critical Control Points (HACCP) concept (ICMSF, 1988). In spite of the fact that cereal products usually have a rich microflora of bacteria, moulds and yeasts, the results of this study showed that the microbial load of raw macaroni is low. The study did not establish any significant difference in the microbial load of raw local and imported macaroni (Table 1). Cooking, which has been identified as a critical control point, destroys vegetative cells and most microbial spores. The effect of cooking has been demonstrated by this study, which has indicated that fresh laboratory-cooked samples of macaroni had lower AMC of $2.4 \log _{10} \mathrm{CFU} / \mathrm{g}$ compared to the AMC of 3.6 and $3.0 \log _{10} \mathrm{CFU} / \mathrm{g}$ recorded for raw local and imported macaroni, respectively.

\section{Effect of holding and bulk display}

Bulk display, holding and serving of waakye are critical points during which germination of spores, growth of vegetative cells and cross contaminations occur in macaroni. While holding a relatively smaller quantity of freshly-cooked macaroni in the laboratory under ambient conditions for $4 \mathrm{~h}$ resulted in only one log-cycle increase in AMC, macaroni from waakye examined $2 \frac{1}{2}$ and $4 \frac{1}{2}$ h later had significantly higher AMC of 8.4 and $7.1 \log _{10} \mathrm{CFU} / \mathrm{g}$, respectively. Coliforms were not detected in the uncooked and laboratorycooked macaroni. However, all vendors sampled had coliforms with a steady increase from $2.5 \log _{10}$ $\mathrm{CFU} / \mathrm{g}$ at dawn to $7.3 \log _{10} \mathrm{CFU} / \mathrm{g}$ after only $2 \frac{1}{2} \mathrm{~h}$ followed by a decrease to $5.6 \log _{10} \mathrm{CFU} / \mathrm{g}$ after $41 / 2$ h. Moulds and yeasts also increased steadily to $2.9 \log _{10} \mathrm{CFU} / \mathrm{g}$ after $2 \frac{1}{2} \mathrm{~h}$ and $4.1 \log _{10} \mathrm{CFU} / \mathrm{g}$ after $41 / 2 \mathrm{~h}$. These results generally indicated increases of 2-5 log cycles in the AMC, CC and MYC in macaroni sampled from waakye vendors in the morning (early and late) compared to those at dawn. In addition, six coliform isolates (four of which were not present in the dawn samples) were detected in the morning (early and late) macaroni. These findings emphasised the roles of holding and bulk display as important critical points in determining the microbial quality of macaroni as has also been reported in other studies on street foods. (Bryan et al., 1988; Bryan et al., 1992; Mosupuye \& von Holy, 1999).

\section{Cross-contamination by vegetable salads}

As can be seen from the high microbial counts in the vegetable salads, it is evident that they contributed immensely to the poor quality of 
macaroni, possibly through cross contamination during serving by vendors. The high microbial counts in vegetable salads shown in Table 2 support the study by Nketsia-Tabiri, Adu-Gyamfi \& Owusu-Biney (2004), which also suggested cross-contamination from vegetable salads to macaroni. The poor microbial quality of vegetables such as lettuce and cabbage has been reported in other studies (Farkas et al., 1997; Beuchat, 1995, 1996; WHO, 2002; Tano-Debrah, 2004), and attributed to their origin, cultivation practices and minimal processing. Careful consideration of the results revealed the similarity of the coliform profiles of macaroni and vegetable salads. The presence of Escherichia coli, Klebsiella spp. and Citrobacter spp. on both macaroni and vegetable salads sold by vendors in the morning further confirms the role of cross contamination by the vegetable salads.

\section{Presence of pathogens}

The isolation of Salmonella, Escherichia coli, Klebsiella spp. and Serratia spp. from macaroni and the vegetable salads poses food safety problems since they are all enterotoxigenic and cause gastroenteritis (Stewart \& Beswick, 1977; Klipstein, Engert \& Short, 1977; Anon., 1996). Other studies have also identified pathogens including Salmonella spp. on other street foods and their accompaniments in South Africa (Mosupuye \& von Holy, 1999) and Zambia (Bryan et al., 1997). While Salmonella sp. causes salmonellosis and typhoid fever, E. coli O157:H7 causes severe illness and deaths, especially among children in several countries (WHO, 2002).

\section{Conclusion}

The nature and cooking of macaroni are adequate to ensure acceptable hygienic quality in waakye. Cross-contamination from vegetable salads and poor handling during the holding and bulk display periods cause deterioration in microbial quality of macaroni. The presence of potential foodborne pathogens in macaroni and vegetable salads raises serious food safety concerns and calls for urgent action. In addition to the provision of infrastructure and enforcement of bye-laws and codes of practice on street foods, emphasis should be placed on educating vendors on simple preventative steps of keeping food hygienically safe.

\section{Recommendations}

Aside the major recommendations of providing basic infrastructure and enforcement of bye-laws and codes of practice on street foods, the education of vendors should emphasise the importance and observation of the following simple steps in keeping food safe from harmful microorganisms:

i. Using properly washed good quality raw materials.

ii. Washing hands before meals are prepared and frequently during the sale of food.

iii. Cooking food adequately and not re-using leftover food.

iv. Keeping foods separate to prevent cross contamination between raw (or minimallyprocessed) and cooked foods.

\section{Acknowledgement}

The author is grateful to Messrs E. Akolmolga and T. Mahami of the Department of Food Science and Radiation Processing, BNARI/GAEC, for their technical assistance.

\section{References}

ANon. (1996) Intestinally pathogenic Escherichia coli. In Microorganisms in Foods. (5), $1^{\text {st }}$ edn. ICMSF. Blackie Academic \& Professional Press. pp.126140.

Apha (1976) Compendium of Methods for the Microbiological Examination of Foods. (M.K. Speck, ed.) American Public Health Association, Washington, D.C.

Beuchat, L. R. (1995) Pathogenic microorganisms associated with fresh produce. J. Fd Prot. 59(2), 204-216.

Bryan, F. L. , Mechanie, S. C., Alvarez, P. \& Paniagua, 
D A. (1988) Critical control points of street-vended foods in the Dominican Republic. J. Fd Prot. 51, 373-383.

Bryan, F. L., Jermini, M., Schmitt, R., Chilufya, E. N., Mwansa, M., Matoba, A., Mfume, E. \& Chibiya, H. (1997) Hazards associated with holding and reheating foods at vending sites in a small town in Zambia. J. Fd Prot. 60, 391-398.

Bryan, F. L., Riaz, S., Tuefel, P., Rooh, S., Qadar, F. \& MaLIK, Z. (1992) Hazards and critical control points of street-vended chat, a regionally popular food in Pakistan. J. Fd Prot. 55, 708-713.

Castelvertri, F., Abroggi, F. \& Gola, S. (1986) Microbiological stabilization of pasteurised fresh meat-filled pasta products with water activity lower than 0.94. Ind. Conserv. 61(4), 333-337.

DAwSON, R. J. \& CANET, C. (1991) International activities in street foods. Fd Control 2, 135-139.

EKANEM, E. O. (1998) The street food trade in Africa: Safety and socio-environmental issues. Fd Control 9, 211-215.

Farkas, J., Saray, T., Mohacsi-Farkas, C., Horti K. \& ANDRASSY, E. (1997) Effects of low-dose gamma radiationon shelf-life and microbiological safety of pre-cut/Prepared vegetables. Adv. Fd Sci. (CMTL) 19(3/4), 111-119.

Fao/Ghana (1997) Survey on the Street Food Situation in Ghana (SFSIG). FAO, Rome. pp. 42-50.

ICMSF (1988) Microorganisms in Foods. 4. Application of the Hazard Analysis Critical Control Point (HACCP) System to Ensure Microbiological Safety and Quality, Blackwell Scientific Publications, Oxford.

Klipstein, F. A. Engert, R. F. \& Short, H. B. (1977) Relative enterotoxicity of coliform bacteria. J. Infec. Dis. 136, 205-215.

Lopez, C. C., Vanini, L., Lanciotti, R. Guerzoni, M. E. (1998) Microbiological quality of filled pasta in relation to the nature of heat treatment, J. Fd Prot. 61(8), 994-999.

Lee, W. H. Staples, C. L. \& Olson JR., J. C. (1975) Staphlococcus aureus growth and survival in macaroni dough and the persistence if enterotoxins in the dried products. J. Fd Sci. 40, 119-120.

MAC FAdDin, J. F. (1980) Biochemical Tests for Identification of Medical Bacteria Williams and Wilkins, Baltimore, USA.

Mosupuye, F. M. \& von Holy, A. (1999) Microbiological quality and safety of ready- to- eat street-vended foods in Johannesburg, South Africa. J. Fd Prot. 62(11), 1278-1284.

Moy, G., Hazzard, A. \& Kaferstein, F. (1997) Improving the safety of street-vended food. Wld Hlth Stat. Q. 50, 124-131.

Nketsia-Tabiri, J., Adu-Gyamfi, A. \& Owusu-Biney, A. (2006). Irradiation of ready meals for microbiological safety and shelf-life extension. 1. Microbiological quality of waakye and other readyto-eat meals. Ghana J. agric. Sci. 39(1), 19-24.

Pasolini, B., Aloi, M. \& Ceralli, M. (1981) Various types of fresh pasta: Preliminary studies on the microflora, with special consideration of pathogens (Salmonella, staphylococcus, Clostridium perfringens). Riv. Soc. Ital. Sci. Aliment. 3, 165174.

Stewart, F. S. \& Beswick, T. S. L. (1977) Commensal intestinal bacteria. In Bacteriology, Virology and Immunity for Students of Medicine, $10^{\text {th }}$ edn. Cassel \& Collieer Macmillan Publishers Ltd. pp. 233238.

Swanepoel, F. J. J., Нobbs, C., Becker, P. J. \& IJSSELMUIDEN, C. (1995) The quality of food sold by traders in central Johannesburg and factors associated with contamination. J. Compr. Hlth $\mathbf{6}$, 188-190.

Tano-Debrah, K. (2004) Danger, ready-to-eat foods in plastic sachets. Daily Graphic, No. 149178, July16, 2004, p. 7.

Wallace, P. A. (2004) A case study of street food situation in Kumasi: Socio-economic aspects and sanitary practices. Agric. Fd Sci. J. Ghana 3, 203216.

Wно (2002) WHO Global Strategy for Food Safety: Safer Food for Better Health. Food Safety Issues, WHO, Geneva. 